NJE Vol. 36: 1-10, 2020

Nigerian Journal of Entomology

Published by the Entomological Soc. of Nig.

www.esnjournal.com.ng

DOI.10.36108/NJE/0202/63.01.10

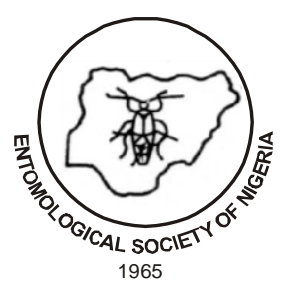

\title{
Biodiversity and Conservation in Entomology in the 21st Century: An Overview
}

\author{
Lale, N. E. S., ${ }^{1}$ Omoloye, A. A., ${ }^{2}$ Zakka, U. ${ }^{1}$ and Ojumoola, O. A. ${ }^{3}$ \\ ${ }^{1}$ Crop and Soil Science Department, University of Port Harcourt, Port Harcourt \\ ${ }^{2}$ Department of Crop Protection and Environmental Biology, University of Ibadan, Nigeria \\ ${ }^{3}$ Department of Crop Protection, University of Ilorin, Nigeria
}

\begin{abstract}
Biodiversity accounts for the variability among living organisms and its conservation presents insights for mitigating the problem of depletion or exhaustion of biological resources. From the simplest level of genes, species, and ecosystems; biodiversity provides a wide range of goods and services for survival with potential direct or indirect utilization by humans. Biodiversity is key as it constitutes the rich biological resources that typically measures all variations at the genetic, species and ecosystem level and is particularly important for nutrient recycling in soil fertility maintenance; purification of water and air and detoxification of wastes as well as for mitigating pollution and moderation of floods and droughts. It is also invaluable for protecting watersheds and combating erosion; stabilization of climate; and control of pests and diseases. The diversity of insect species is unparalleled being estimated at 1.5 million species but biodiversity is generally threatened in Nigeria by high population growth rate, poverty, policy and legislation constraints as well as poor land use planning and climate change among others. The direct threats to biodiversity in Nigeria include habitat degradation, unsustainable agricultural practices and unsustainable harvesting of biological resources among others. The major approach to biodiversity conservation in Nigeria is the protected-area system and the establishment of a National Insect Museum to be domiciled in one of the Federal Universities is key.
\end{abstract}

Keywords: Biological resources, Nutrient recycling, Habitat degradation, National Insect Museum.

\section{INTRODUCTION}

Biological diversity (=Biodiversity) is key to applied knowledge via discovery of how and to what extent, different organisms have evolved, interacted and adapted well to fit their various environments where they are normally found (Wilson 1992). This implies

\footnotetext{
*Correspondence email:
}

that biodiversity may present the potential insights for the much desired solutions to the problem of depletion or exhaustion of biological resources, whether in the current or future. Onyekwelu (2017) ruminated on the idea of a life on Earth; that is devoid of diversity and concluded that every imaginable scenario would be boring, uninteresting, uninviting and presumably 
meaningless or chaotic. This may explain why nature; in order to putatively avoid these as well as other innuendoes, has bequeathed the universe as we have it today with built-in diversity in all forms of life. It is particularly worth noting that the individual components of biodiversity from the simplest level of genes, species, and ecosystems; provide the Universe with a wide range of goods and services for survival. For instance, the genes, species, and ecosystems have potential (direct or indirect) utilization by humans and these constitute the rich biological resources; the importance of which have dominated discussion for a long time; including the deleterious effects of climate change on the species composition in the ecosystem (McNeely and others 1990; Reid and Miller 1989; Wood 1997). This knowledge has been exploited directly by plant breeders in developing new crop varieties; especially those among them, that have been adopted and exploited for use in various foods, medicines, and industrial products. This knowledge is also relevant in view of the relevant ecosystems services such as water purification and flood control. Thus, biodiversity is viewed in this presentation as that which sets the stage for survival of all organisms in the ecosystem and is assessed within the context of contemporary challenges as well as the needed necessary interventions via concerted efforts at conservation of the very rich peculiar biological diversity of Nigeria.

\section{Biodiversity in context}

Biological diversity as a concept appears to be easier to appreciate than define. Heywood et al. (1995) defined biodiversity as the total variability of life on earth. This definition is admirably compact and all inclusive; yet, biodiversity could mean the variety of life in the world or within a particular habitat or ecosystem. Many biologists have frequently defined biodiversity as the totality of genes, species and ecosystems of a region (Barbault and Sastrapradja, 1995). Perhaps the most popular of the definitions is that used by United Nations Convention on Biological Diversity which defines biodiversity as 'the variability among living organisms from all sources, including terrestrial, marine and other aquatic ecosystems and the ecological complexes of which they are part; which includes diversity within species, between species and of ecosystems' (ITTO, 2008). Biodiversity therefore typically measures all variations at the genetic, species and ecosystem level, hence the three main types: diversity within species (genetic diversity), between species (species diversity) and between ecosystems (ecosystem diversity).

\section{Types of Biodiversity}

Biodiversity is commonly explored at three levels: genetic diversity, species diversity and ecosystem diversity and these three levels work together in synergy to creating the varied complexity of the different lifeforms on Earth. With variability at each of these levels of biodiversity, all species, ecosystems and the general health of the universe benefit. In fact a greater biodiversity provides a somewhat insurance such that when there is ecological disturbance, biodiversity assists in restoration and survival. The three main types are described briefly.

\section{Genetic diversity}

This is the variety of genes contained within a species. Each species in life is made up of individuals that have their own particular genetic composition. This means that a species may have different populations, each having different but unique genetic compositions. The genes are the basic units of all life on Earth. Genetic diversity has 
remained a factor that is responsible for both the similarities and differences between organisms in a particular ecosystem.

\section{Species diversity}

This is the occurrence of a variety of species within a habitat or a region. Some major habitats such as the terrestrial rainforests and the coral reefs, have many species whereas others, such as a polluted stream have a comparatively fewer diversity of species. The diverse species are grouped together into families according to the characteristics they have in common. The invertebrate as a group which consists of the animals without backbones make up about $99 \%$ of all animal species; most of which are insects. The invertebrate species include crabs, snails, worms, corals and seastars as well as the insects such as the beetles, the butterflies, the bees and the flies. Generally, insects perform many vital roles in the ecosystems as pollinators of crops, recyclers of nutrients while they serve as scavengers and food for others. Although may often be quite visibly encountered in the ecosystem, vertebrates constitute a very small percentage; indeed less than $1 \%$ of total animal species.

\section{Ecosystems Diversity}

This refers to the variability in the habitats that are found within a geographic area. The ecosystem takes into cognizance both the biological and the non-biological drivers of variability such as temperature and light. Areas with characteristic high ecosystem diversity are indicative of geographically distinct mosaic communities which protect the delineated area from drastic ecological disturbances and changes. For example, the dry savanna ecosystem of Nigeria with dry vegetation; especially in the dry periods, may become susceptible to wild fires.

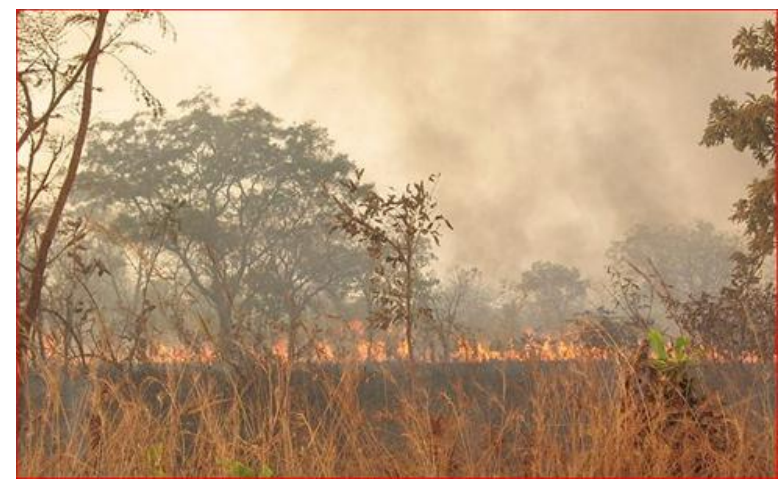

Fig. 1: Bush fire in the Nigerian savannah Source: https://www.nta.ng/agriculture/ 20181130-national-park-service-to-holdcampaigns-on-bush-burning/

However where such spots are surrounded by less sensitive ecosystems, the wild fires may not spread, thus allowing the diverse species to shift to nearby favorable ecosystems. Thus, ecosystem helps to protect and maintain species diversity.

\section{Ecological role of biodiversity and influence on Agriculture}

Our natural biologically diverse ecosystems as they present today provide many benefits as vividly captured by Oke (2016). Biodiversity is important in meeting human needs while maintaining the ecological processes upon which our environment depends. Biodiversity is directly beneficial to Agriculture as the rich biological resource with particular reference to food plants and domestic animals, medicine (for drugs which are derived from many plants, animals and microorganisms) and energy from fuel wood and fossilized plants. Biodiversity thus forms the basis for food chains and food webs in the maintenance of ecological balance (Table 1, Fig. 2,). 
Table 1: Examples of food chain

\begin{tabular}{llll}
\hline Trophic level & Grassland biome & Pond biome & Ocean biome \\
\hline Primary Producer & Grass & Algae & Phytoplankton \\
Primary Consumer & Grasshopper & Mosquito larvae & Zooplankton \\
Secondary Consumer & Rat & Dragonfly larva & Fish \\
Tertiary Consumer & Snake & Fish & Seal \\
Quaternary Consumer & Hawk & Racoon & White shark \\
\hline
\end{tabular}

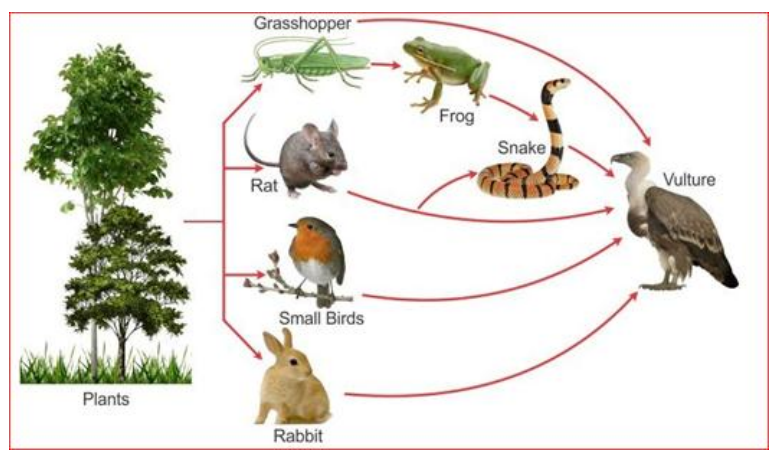

Fig. 2: A food web

Source: Adapted from: https://www.topper learning.com/answer/explain-food-webgiving-suitable-examples/53f5yqii

Biodiversity is required for nutrient recycling in soil fertility maintenance; and also provides for purification of water and air, and detoxification of wastes; thus mitigating pollution; moderation of floods and droughts. It is particularly invaluable for protecting watersheds and combating erosion; stabilization of climate; and control of pests and diseases. Biodiversity also has aesthetic and cultural benefits (Onyekwelu, 2017).

However, a change in the composition and abundance of the species that make up an ecosystem can alter the above iterated services. Biodiversity enriches our knowledge in ways that are both informative and transformative. For example, knowing the components of biodiversity is valuable in stimulating technological innovation and in learning about human ecology and survival while at the same time, increasing our knowledge of biodiversity transform our values and beliefs especially about preservation and conservation of biological species in nature. There is a fairly robust literature characterizing the non-extractive ecosystem services with direct benefit to society, such as water pollution and purification, flood management and control, pollination, as well as pest control. Yet, such services in biophysical and economic terms characterize the institutional mechanisms that are required to generate interests and necessary incentives for their preservation.

\section{Insect biodiversity conservation}

Hornby (2015) in Oxford Advanced Learner's Dictionary of Current English defined conservation as the protection of the natural environment; preventing it from being lost, wasted, damaged or destroyed. This review, however, focuses on the biological environment and therefore on conservation biology hereafter called bioconservation. Conservation biology has been defined as the management of nature and of earth's biodiversity with the aim of protecting species, their habitats, and ecosystems from excessive rates of extinction and the erosion of biotic interactions.

Clearly, Conservation Biology has three goals: 
(1) to investigate and describe the diversity of the living world;

(2) to understand the effects of human activities on species, communities, and ecosystems; and

(3) to develop practical interdisciplinary approaches to protecting and restoring biological diversity.

Conservation biology is important in at least two respects. First, we work to conserve endangered species by manipulating their environment to improve chances for their survival. Secondly, we conserve as much of the natural ecosystems as we can. When we conserve biodiversity properly, then all the benefits enumerated previously will accrue to us.

\section{Biodiversity and conservation in entomology}

The species diversity of insects is unequivocally unparalleled in the living world. One of many estimates is that there are 1.75 million named organisms in the living world of which 1.5 million are species of insects (Van Emden, 2013). Current estimates of total insect diversity varies from 2.6-7.8 million species with a mean of 5.5 million (Stock et. al., 2015). Beetles (Order Coleoptera) make up $40 \%$ of described insect species. You can then clearly see that Professor Haldane had a point!

The dominance of the six-legged arthropods in biodiversity is replicated in Nigeria. Nigeria is rich in biodiversity comprising about 1, 248 species of microorganisms, 7, 285 plant species and 22, 000 vertebrates and invertebrate species (of which about 20, 000 are insect species) (Federal Ministry of Environment, 2001).

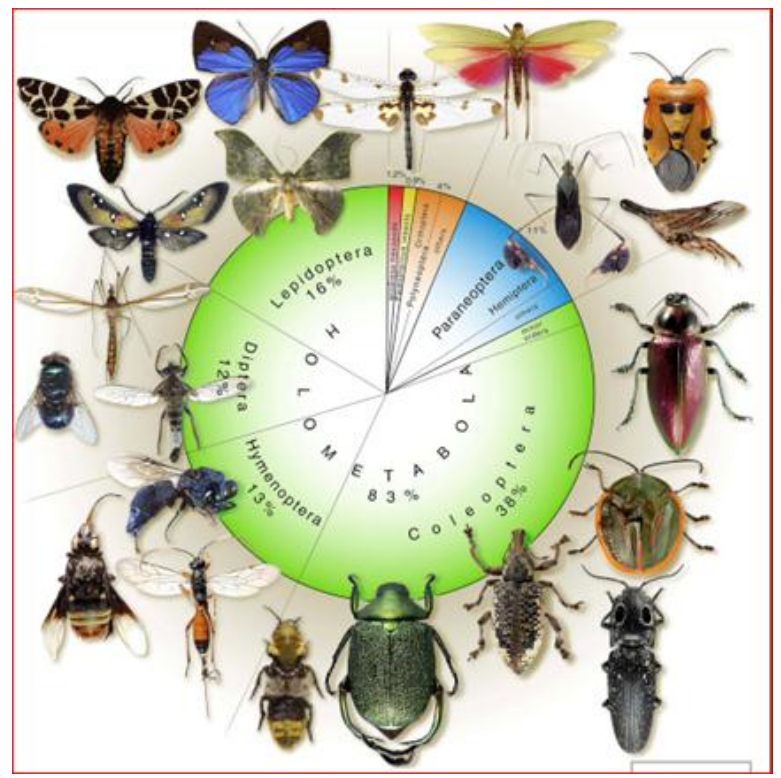

Fig. 4: Diversity of Insects in the ecosystem Source: Adapted from https://www.cell.com/ current-biology/comments/S09609822(15)00927-6\#figures

Insects are important because of their diversity, ecological role, and influence on agriculture, human health and natural resources (Scudder, 2017). Insects create the biological foundation for all terrestrial ecosystems. They cycle or recycle nutrients (e.g. termites), pollinate plants (bees and butterflies), disperse seeds (seed bugs, wasps and ants), maintain soil structure and fertility (e.g. springtails) and control populations of other organisms as predators and parasitoids (e.g. coccinellid beetles and braconid wasps), and provide a major food source for other organisms including man (entomophagy). Major insect pests in agriculture are nonnative species that have dvbeen introduced into new ecosystem, usually without their natural biological control agents. Insects have evolved unique features in the animal 
world that are a surprise to experts in biomechanics and bioengineering because many are recent inventions of humans. Insects have been in competition with humans for the products of our labour since cultivation of soil began (Ofuya, 2003; Lale, 2010). Perhaps, without insects and possibly other invertebrates, human life on this planet may have been impossible.

\section{Diversity of Nigerian insects}

We may just have a fair knowledge of insect biodiversity in Nigeria. Libby (1968) provided a list of insect pest species of Nigerian crops and Hywel (1969) compiled the forest insects of Nigeria and many authors have reported many indigenous aquatic insect species (e.g. Edegbene and Arimono, 2012; Ada et al., 2017; Okoro et al., 2017). Figures that may have been given for the number of insect species in Nigeria are at best guesstimates. It is doubtful whether new collections and identifications of insect species are being done anywhere in Nigeria. Literature is quite scanty or perhaps nonexistent concerning endangered insect species in Nigeria whereas there is some information on threatened or endangered plants (Gbile et al., 1981; Gundu and Adia, 2014) and vertebrates (Aremu, 2010). In the USA in 2017 over 80 insects were classified as endangered species the majority of which were beetles and butterflies (Anonymous, 2017) and efforts are being made for their deliberate conservation.

\section{Perceptions and taxonomic impediments to insect conservation in Nigeria}

According to Samways (1993), the lack of human appreciation of the vital role of insects in ecosystems coupled with the general disregard and dislike of these sixlegged creatures, is an enormous perception impediment to their conservation. Additionally, there is the impediment of bureaucracy concerning identifications and field research permissions which sort of discourage some scientists in several countries of the developed world and some developing countries (Audisio, 2017). There is undoubtedly increasing difficulties in moving entomological and zoological materials across countries through the borders, airports, customs, postal services, etc.

Maintenance of insect museums or collections where they exist is rather poor and many specimens are being destroyed and lost. We have very few insect taxonomists in the country and only a small percentage of Nigerian insects have actually been scientifically described. This taxonomic impediment i.e. the lack or the shortage of qualified professionals or amateur taxonomists and of financial resources to conduct biodiversity and conservation work is characteristic of several other countries (Samways, 1993; Audisio, 2017). The perception and the taxonomic impediments must be overcome for realistic insect biodiversity conservation in Nigeria. As it is not possible to know all the species relative to the rate at which they are becoming endangered or extinct, it is essential to conserve as many biotypes and landscapes as possible.

\section{Threats to biodiversity in Nigeria}

Biodiversity is threatened globally and the main factors to this threat in Nigeria have been indicated by many workers (Kehinde et al., 2014; Audu and Ayuba, 2016; Oke, 2016). The underlying factors threatening biodiversity in Nigeria include high population growth rate, poverty, policy and legislation constraints, poor land use planning, governance and transparency, socio-cultural characteristics, food and trade connections and climate change. The direct 
threats to biodiversity in the country include habitat degradation, unsustainable agricultural practices, unsustainable harvesting of biological resources, extractive industries and their activities, unsustainable natural resource harvesting, poaching, fuel wood consumption, illegal logging, uncontrolled, illegal and bush burning practices, unsustainable harvesting of non-timber forest products, pollution, gas flaring, invasive species, overgrazing and bush fires. The effect of changing climate in our time on insect biodiversity also deserves a mention. Bradford and Andres (2018) convincingly documented remarkable declines in tropical arthropod abundance in Puerto Rico due to climate change over the past four decades. Putatively, climate change may have already claimed many insect victims in Nigeria. This should be subjected to empirical verification.

\section{Biodiversity losses and priority attention to national conservation}

While biodiversity loss is a global problem, conserving habitat specifically for species of insects is uncommon and generally of low priority. The shrinkage of natural ecosystems under pressure from increasing human population, intensification of agriculture and urbanization/infrastructural development appears crucial among the set of factors that degrade the environment and threaten biodiversity in Nigeria (Aju and Ezeibekwe, 2010; Oke, 2016). Many studies carried out in parts of the tropics and subtropics (Holloway et al., 1992; Eggleton et al., 1995; Watt et al., 1997; Kitching et al., 2000) have actually shown that deforestation as well as other forms of habitat disturbance can cause a reduction in insect abundance and species richness.

\section{Major approaches to biodiversity conservation in Nigeria}

The major approach to biodiversity conservation in Nigeria which is perhaps embraced globally is the protected-area system (Audu and Ayuba, 2016). The categories of biodiversity related sites in Nigeria include National Parks (7), World Heritage sites (2), Forest Reserves (994), Game Reserves (32), Biosphere Reserve (1), and Sacred Groves (Federal Ministry of Environment, 2015). Your guess is as good as mine concerning how these supposedly protected sites are achieving the aims and objectives for their establishment in Nigeria. Suffice it to say without equivocation that threats and dissonant tunes characterize the biodiversity conservation orchestra in Nigeria.

\section{Call for establishment of a national agency for conservation}

It has been suggested that biodiversity and conservation education can be facilitated and popularized by being deliberately introduced to all learners at different stages of life in Nigeria (Gbile et al., 1981). All public and private business organizations and agencies in Nigeria should incorporate biodiversity conservation programmes in their operations and checks to ensure compliance must be put in place. This may partly mitigate the perception impediment to biodiversity conservation. It has also been suggested that an International Agency be put in place to formulate a best practice policy in order to more properly and wisely combine conservation biology, national policies on biodiversity management, international scientific research on systematics and taxonomy, and preservation and improvement of public zoological collections (Entomological Society of America, 2017). The Agency will work in tandem with the Convention on Biological Diversity. Nigeria signed the Convention on Biological Diversity in 1992 and ratified it in 1994 and thereby being committed to the objectives. Without doubt Nigeria is good at signing 
agreements that will make the world a better place and we are not deficient in sending officials to planned meetings ensuing from these agreements. However, follow-up activities to be carried out in the country for progress are often left undone.

\section{Overview of biodiversity conservation concerns in the Nigerian environmental policy}

It appears that biodiversity conservation concerns are just barely included in Nigeria's environmental policy (ENN, 2019). This is simply outrageous and ludicrous. Proper legislation is urgently needed and a policy document specific to biodiversity and conservation embracing all ramifications of the subject should be produced for implementation.

\section{Need for review of funding strategies for biodiversity conservation}

There is need for a review of funding strategies for biodiversity conservation to ensure adequate financial allocation to the ministries, agencies and other relevant establishments and organizations concerned with the environment, biodiversity and conservation. The funding strategy must necessarily address overcoming the dearth of trained and skilled manpower (taxonomists, ecologists, biologists, etc) and appropriate technologies.

\section{Recommendations and Conclusion}

There is the need for a National Insects Museum to be domiciled in one of the Federal Universities. The necessity and the benefits of the museum cannot be overemphasized or distorted. It is paramount to insect biodiversity and conservation issues in Nigeria. The Entomological Society of Nigeria should champion the realisation of the establishment of the museum, but the modus vivendi would require wider consultations and discussions, and may form a major item on the agenda of the Annual General Meeting of this Conference. The Almighty God gave us the earth to live in, tend and keep for posterity. We should, therefore, wisely use the resources we have been blessed with for posterity.

\section{REFERENCES}

Ada, R.T., Iorshagher, S.T. and Akogwu, E.A. (2017). Survey and identification of macroinvertebrates found in ponds in Makurdi, Benue State, Nigeria. International Journal of Ecotoxicology and Ecobiology 2: 26-32.

Ajayi, F.A.. Okrikata, E. And Allahnana, A.M. (2018). Diversity and abundance of insects in and around Faculty of Agriculture, Shabu-Lafia Campus of Nasarawa State University, Nigeria. International Journal of Applied Research and Technology 7 (4): 22-29.

Audisio, P. (2017). Insect taxonomy, biodiversity research, and the taxonomic impediments. Fragmenta entomologica 49 (2): 121-124.

Anonymous (2017). Conserving the Nature of America. ECOS Environmental Conservation Online System. US Fish and Wildlife Service.

Aju, P.C. and Ezeibekwe, I.O. (2010). Understanding and appreciating the need for biodiversity conservation in Nigeria. Journal of Medicinal Plants Research, 4 (24): 2605-2608.

Aremu, O.T. (2010). The diversity and distribution of mammals in Nigeria. In: Practical Issues in Forest and Wildlife Resources Management, Edited by H.M. Ijeomah and A.A. Aiyeloja, pp. 552-581.

Audu, H. and Ayuba, G.M. (2016). Biodiversity conservation in Nigeria: Contemporary Challenges for Ecologists. International Journal of Innovation and Applied Studies 18: 331-340.

Barbault, R. and Sastrapradja, S.D. (1995). Generation, maintenance and loss in 
biodiversity: Global Biodiversity Assessment. Cambridge University Press, Cambridge, pp. 193-274.

Bradford, C.L. and Andres, G. (2018). Climate-driven declines in arthropod abundance restructure a rainforest food web. Proceedings of National Academy of Sciences 115 (44): E10397-E10406.

Edegbene, A.O. and Arimono, F.O. (2012). Ecological status of owan river, southern Nigeria using aquatic insects as bioindicators. Journal of Aquatic Sciences 27: 99-111.

Eggleton, P., Bignell, D.E., Sands, W.A., Waite, B., Wood, T.G. and Lawton, J.H. (1995). The species richness of termites (Isoptera) under different levels of forest disturbance in the Mbalmayo Forest Reserve southern Cameroon. Journal of Tropical Ecology 11: 85-98.

ENN (2019). How Nigeria strives to achieve biodiversity conservation targets by CBD. News Bulletin. A project of MS \& Associates, Nigeria Entomological Society of America (ESA), 2017. ESA Position on the Importance of Entomological Collections. Annals of Entomological Society of America 110 (6): 565-566.

Federal Ministry of Environment (2001). First National Biodiversity Report. Federal Ministry of Environment, Abuja, Nigeria.

Federal Ministry of Environment (2015). Fifth National Biodiversity Report. Federal Ministry of Environment, Abuja, Nigeria.

Gbile, Z.O., Ola Adams, B.A. and Soladoye, M.O. (1981). List of rare species of the Nigerian flora. Research Paper (Forest Series) 47, FRIN, Ibadan, Nigeria.

Gundu, E.G. and Adia, J.E. (2014). Conservation methods of endangered species. Journal of Research in Forestry, Wildlife and Environment 6: 76-83.

Heywood, V.H., Baste, I. And Gardner, K.A. (1995). Introduction. In:Global Biodiversity Assessment, Edited by V.H. Heywood, pp. 1-19, Cambridge University Press, Cambridge, UK.

Holloway, J.D., Kirk-Sprigss, A.H., Chey, V.K. (1992). The response of some rain forest insect groups to logging and conversion to plantation. In: Tropical Rain Forest: Disturbance and Recovery, Edited by Marshall, A.G. and Swaine, M.D., Philosophical Transactions of the Royal Society, pp. 425-436, Alden Press, Royal Society.

Hornby, A.S. (2015). Oxford Advanced Learner's Dictionary of Current English. 9th Edition. Oxford University Press, Oxford, UK. 832pp.

ITTO (2008). Status of tropical forest management. Tropical Forest Update 18: 1-29.

Kehinde, T., Amusan, B., Ayansola A., Oyelade, S. and Adu, W. (2014). Status of insect diversity conservation in Nigeria: A Review. Ife Journal of Science 16: 319-330.

Kitching, R.L., Orr, A.G., Thalib, L., Mitchell, H., Hopkins, M.S. and Graham, A.W. (2000). Moth assemblages as indicators of environmental quality of Australian rain forest. Journal of Applied Ecology 37: 284297.

Oke, S.O. (2016). Forest Biodiversity: Importance, Threats, Restoration and Conservation. In: Advances in Biological Sciences, Edited by C.O. Adedire and O.A. Fagbenro, pp. 259-268, Artsmosfares Prints, Ibadan, Nigeria.

Okoro, J.O., Nnamonu, E.I., Okoye, I.C., Onyishi, G.C., Obiezue, R.N. and Ozioko, K.U. (2017). Ecology of Class Insecta in Opi lake, Nigeria. International Journal of Research in Pharmacy and Biocsiences 4: 24-30.

Onyekwelu, J.C. (2017). Plant and Animal Species Diversity as Sources of Functional Food Products in sub-Saharan Africa. In: Functional Foods: Unlocking the Medicine in Foods, Edited by G. Oboh, pp. 351-383, Graceland Prints, Akure, Nigeria.

Samways, M.J. (1993). Insects in biodiversity conservation: Some perspectives and directives. Biodiversity and Conservation: 258282.

Scudder, G.G.E. (2017). The Importance of Insects. http://doi.org/10.1002/978111845568. Chapter 2. 
Stork, N.E., McBrown, J., Gely, C. and Hamilton, A.J. (2015). New approaches narrow global species estimates for beetles, insects and terrestrial arthropods. Proceedings of National Academy of Sciences 112: 201502408.

Van Emden, H.F. (2013). Handbook of Agricultural Entomology. Wiley-Blackwell. 312pp.
Watt, A.D. Stork, N.E., Eggleton, P., Srivastava, D., Bolton, B., Larsen, T.B. and Brendell, M.J.D. (1997). Impact of forest loss and regeneration on insect abundance and diversity. In: Forests and Insects, Edited by Watt, A.D., Stork, N.E. and Hunter, M.D., pp. 274-286, Chapman.

NJE Vol. 36: 1-10, 2020

Nigerian Journal of Entomology

Published by the Entomological Soc. of Nig.

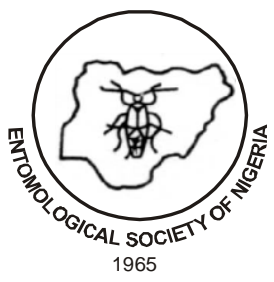

www.esnjournal.com.ng

DOI.10.36108/NJE/0202/63.01.10 